\title{
Высотная мезозональность - вариант орографической зональности ландшафтов центра Русской равнины
}

\author{
С. В. Федотов $凶$ \\ Воронежский государственньй университет, Российская Федераџия \\ (394018, г. Воронеж, Университетская пл., 1)
}

\begin{abstract}
Аннотация: Цель исследования - провести анализ орографической зональности в центре Европейской России как конкретное выражение высотной дифференциации равнинных ландшафтов. Материаль и методы. Исходными материалами послужили данные полевых ландшафтных исследований на юге зоны смешанных лесов и лесостепья в течение 1990-2020 годов. Основной метод исследования - ландшафтно-аналитический. Результаты и обсуждение. На основе регионального полевого материала раскрывается структура высотных мезозон Придеснинья, Окско-Донской равнины, Среднерусской возвышенности. Каждая мезозона соответствует определенному уровню абсолютных высот низменно-гидрогенная (125-150 м), высоко-гидрогенная (150-180 м), возвышенно-гидрогенная (180220 м), возвышенно-денудационная (180-220 м), возвышенно-водораздельная (220-250 м) и холмистоводораздельная (250-и более м). Заключение. Центр Русской равнины - регион, где орографический вариант зональности представлен разнообразным спектром высотно-ландшафтных мезозон. На возвышенных равнинах спектр мезозон полный - низмено-гидрогенная; высоко-гидрогенная; возвышенно-гидрогенная; возвышенно-денудационная; вершинно-водораздельная и холмисто-водораздельная. На низменных равнинах спектр ландиафтно-высотных мезозон усеченный - низмено-гидрогенная; высоко-гидрогенная и возвышенно-гидрогенная. Особо следует отметить, что граница высотных интервалов между ландшафтно-высотными мезозонами не всегда жестко сохраняется. Допускается скользящиий вариант грании между мезозонами при переходе с возвышенных равнин к низменным и наоборот.

Ключевые слова: мезозональность, ландшафт, орография, равнина, мезозоны, возвышенность, низменность.

Для цитирования: Федотов С. В. Высотная мезозональность - вариант орографической зональности ландшафтов центра Русской равнины // Вестник Воронежского государственного университета. Серия География. Геоэкология, 2020, № 3, с. 3-12. DOI: https://doi.org/10.17308/geo.2020.3/3017
\end{abstract}

\section{ВВЕДЕНИЕ}

В отечественной историографии изучения вопросов вертикальной дифференциации рельефа Земли насчитывается не одно столетие. Анализ опубликованных по этой проблеме материалов позволяет нам выделить несколько сложившихся в науках о Земле направлений.

Первое. Планетарно-землеведческое. Оно связано с построением и анализом гипсографической кривой - диаграммой, показывающей соотношение площадей ступеней (уровней) материковой суши и абсолютных отметок высот, а также площадей (ступеней и уровней) океанических впадин

() Федотов С. В., 2020

Федотов Сергей Владимирович, e-mail: fsv777@ yandex.ru Контент доступен под лицензией Creative Commons Attribution 4.0 License.

и абсолютных глубин Мирового океана. Интегрировано на гипсографической кривой изображаются маркерные точки расчленения поверхности планеты.

В планетарно-землеведческом направлении сложилось два варианта дифференциации рельефа Земли - планетарно-геофизическое (геоморфологическое) и планетарно-ландшафтное.

Планетарно-геофизический (геоморфологический) вариант на гипсографической кривой отражает две абсолютных отметки - абсолютную высоту планетарной суши - г. Джомолунгма $(8848$ м) и абсолютную глубину Мирового океана - Марианский желоб (11022 м). Следующий маркер - сред- 
няя высоты суши, равная 875 метрам. Это означает, что на материках преобладает форма рельефа, занимающая промежуточное положение между плоскогорьями и низкогорьями. Калесник С.В. среднюю высоту суши 875 метров связывает с материками-плоскогорьями. Маркер средней высоты материков означает, что на суше планеты преобладают высоты ниже 1000 метров, а горы второстепенные детали в рельефе материков.

Здесь будет уместным отметить, что в 1949 году Н. М. Волковым была определена средняя высота территории Советского Союза, равная 430 метрам. Для России, где из расчета выпали Карпаты, Памир, Тянь-Шань и Копетдаг, ее средняя высота скорее всего будет сопоставима или даже близка к самым высоким отметкам возвышенных равнин центра Европейской части - Приволжская возвышенность 375 м, Среднерусская 293 метра.

С помощью гипсографической кривой не трудно установить, что средняя глубина Мирового океана около 3800 метров. На гипсографическом профиле хорошо видно, что континентальный шельф и материковый склон (элементы материковой суши), образуют наклонные поверхности, которыми материки опускаются к ложу океана. В Мировом океане, как показано на графике, преобладают глубины от 3 до 6 км., занимая 75 \% его площади, а следовательно глубоководные желоба, как и горы в рельефе материков, второстепенные формы дна океанов. Изучением особенностей морфологической структуры рельефа планеты активно занимались А. А. Григорьев [8] и С. В. Калесник [14].

Планетарно-ландшафтная интерпретация гипсографической кривой принадлежит Ф. Н. Милькову. На гипсографической кривой он обосновал существование критических ландшафтных точек, закрепляющих высотное положение ландшафтных уровней [19], отражающих области распространения типологических ландшафтов крупного ранга (отделы и классы).

На профиле гипсографической кривой Ф. Н. Мильков выделяет семь ландшафтных уровней. 1. Снеговая граница. Она способствует существованию в ландшафтной сфере Земли отдела ледовых ландшафтов. 2. Уровень 400. Высота 400 метров над уровнем моря обобщенная критическая точка, показывающая интервал перехода ландшафтов равнин в сторону предгорных и горных ландшафтов. На Русской равнине появление нижнего высотного пояса отмечается на Донецком кряже и Приволжской возвышенности с высоты 350 метров. 3. Уровень океана. Это ландшафтная точка на гипсографической кривой показывает смену наземных природных комплексов земноводными и водными ландшафтами континентального шельфа океана. 4. Нижняя границ̧а фотосинтеза (150-200 м). Она практически совпадает с глубинной границей континентального шельфа на котором получили распространение водные комплексы при прямом взаимодействии трех контрастных сред - гидросферы, атмосферы и литосферы с максимально развитым водным биостромом. Континентальный шельф представляет область распространения мелководного класса ландшафтов. 5. Нижняя граница материкового склона, находящаяся на глубине 2500-3000 метров, фиксирует изменение терригенных осадков шельфа и склона на осадки биогенного происхождения. Еще один индикаторный рубеж на подошве материкового склона в месте его стыка с ложем - обеднение органической жизнью абиссальной области. Нижняя граница материкового склона - это граница между батиальной и абиссальной зонами океана. 6. Уровень карбонатной компенсации (4-5 км). Здесь происходит смена карбонатных грунтов на бескарбонатные. Абиссальная область океана - область распространения отдела подводных (донных) ландшафтов, в основе дифференциации которых на географические зоны лежат крупные области распространения илов (радиолярийный, диатомовый, глобигериновый, птероподовый) и глубоководной красной глины. 7. Ультраабиссальный уровень (более 6000 м). Эта область распространения ультраабиссальных ландшафтов, приуроченных к глубоководным желобам и глубоководным впадинам. Место их существования хорошо прослеживается на гипсографической кривой, где происходит резкий прогиб профиля.

Второе. Высотно-ландиафтные уровни материков и структура географической зональности. Первая попытка проанализировать зональную структуру материков на трехмерной модели ландшафтной сферы была предпринята Г. Е. Гришанковым [10]. Главная идея Г. Е. Гришанкова заключается в том, что «на разных высотных уровнях ландшафтной сферы проявление зональности будет различно» (с. 8). В зависимости от особенностей природных сред автор выделяет внутри ландшафтной сферы четыре группы зональных систем - внутреннюю наземную, внешнюю наземную, внешнюю ледовую, океаническую. Эти группы зональных систем, как доказательно объясняет Г.Е. Гришанков, дифференцируются в зависимости от высоты ландшафтных ступеней (уров- 
ней). Например, во внутренненаземной группе зональных систем различается два ландшафтных уровня. Первый представлен плакорной ландшафтной ступенью на высотах от 40 до 200 метров в умеренном поясе и до 800-1000 метров над нулевой отметкой моря в тропическом. Второй - гидроморфными равнинами, которые занимают преимущественно высоты от 25 до 200 метров. Плакорные и гидроморфные равнины отличаются друг от друга и по ландшафтной структуре, и по распространению географических зон.

Гришанков Г.Е. обоснованно приходит к выводу, что наибольшая дифференциация на географические (природные) зоны наблюдается во внутренней группе зональных систем, а во внешней группе дифференциация на зоны резко снижается из-за понижения энергетического баланса, на котором они формируются.

Третье. Высотная дифференциация компонентов равнинных ландиафтов. Начало активного изучения почвенно-растительного компонента ландшафтов, а затем климатического, относятся к временному рубежу - середина XIX - первая половина XX столетия. Во многом специфика компонентов ландшафта была подмечена исследователями при сопоставлении почв, растительности и климатических элементов возвышенных и низменных равнин. В изучении связи растительности (леса и степи) и почв (черноземов и оподзоленных почв) с особенностями мезорельефа на равнинах лесостепи приняли участие классики природоведения конца XIX века - В.В. Докучаев, А. Н. Краснов, Г. И. Танфильев, П. А. Костычев и некоторые другие. Изучению дифференциации растительного покрова в зависимости от контраста равнинного рельефа в первой половине ХХ столетия посвящены работы А.В. Прозоровского, Е. М. Лаврененко, Б. А. Келлера и других.

Климатические различия между возвышенными и низменными равнинами были отмечены А. А. Каминским, Е. Е. Федоровым, С. А. Бастамовым и Н.Н. Изюмовым. Их исследования показывали, что существует разница в климатических условиях между возвышенностями и низменностями в лесостепной зоне Европейской России. Исследования современных климатологов углубляют роль рельефа в появлении климатических эффектов. Так, А. Т. Чуйкова в 60-х годах XX века установила существование фенового эффекта на востоке Среднерусской возвышенности в Лискинском районе Воронежской области, где находится пограничье с Окско-Донской низменностью. Оказа- лось, что водоразделы возвышенности на $1{ }^{\circ} \mathrm{C}$ холоднее, чем рядом расположенные низменные поверхности.

Исследования компонентов ландшафтов возвышенностей и низменностей стали предвестниками принципиально нового подхода к изучению вертикальной дифференциации рельефа равнин ландшафтного.

Четвертое. Ландиафтное направление. Первый опыт выявления закономерностей высотной дифференциации равнинных ландшафтов принадлежит Ф. Н. Милькову [17]. По Ф.Н. Милькову они сводятся к следующему: 1) причина вертикальной дифференциации ландшафтов связана с расчлененностью рельефа и климатом; 2) вертикальная дифференциация ландшафтов - явление внутризональное; 3) если на возвышенных равнинах абсолютные высоты заметно приобретают значительные отметки, то вертикальная дифференциация «должна неизбежно перерастать в вертикальную зональность» (курсив наш - С.Ф.); 4) вертикальная дифференциация преимущественно распространена в лесостепной зоне Русской равнины; 5) признаки вертикальной дифференциации ландшафтов проявляются на контакте соседних природных зон - прямая вертикальная дифференциация свойственна южной половине Русской равнины, где на возвышенностях встречаются элементы северных ландшафтов, а обратная вертикальная дифференциация демонстрирует появление на возвышенностях северных зон южных элементов.

Проблема вертикальной дифференциации равнинных ландшафтов после публикации статьи профессора Ф.Н. Милькова стала на многие годы актуальным направлениям ландшафтных исследований сотрудников и аспирантов кафедры физической географии Воронежского госуниверситета.

В ландшафтном направлении сложилось несколько подходов.

1. Исследование структуры вертикальной дифференциачии в границах ландмафтных провинций лесостепной зоны Русской равнины. Вертикальное структурирование возвышенностей было положено Н.И. Ахтырцевой $[1,2]$ и Ф. Н. Мильковым [16]. На Калачской возвышенности она обосновывает существование четырех вертикальных ярусов - нижних пойменного и террасового, среднего склонового и верхнего водораздельного. Каждый ярус различается сочетанием типологических комплексов ранга доминантных, характерных и редких урочищ. Бердникова 3.П. считает возможным различать ярусную структуру 
склонового типа местности на юге Среднерусской возвышенности. Здесь ею выделяется два яруса средний и верхний. В дифференциации склонов Среднерусской возвышенности 3. П. Бердникова учитывает не только гипсометрический показатель (как само собой разумеющееся), но и степень распространения, структуру и соотношение урочищ [4].

Детальное рассмотрение вертикальной дифференциации ландшафтов низменностей - Приднепровской и Окско-Донской - проведено Г. А. Белосельской [3]. Согласно ее исследованиям, структура низменностей трех уровневая. Однако третий уровень - уровень контактный с рядом расположенной, в одном случае на востоке, а в другом на западе, Среднерусской возвышенностью. Ландшафтная структура низменностей на каждом уровне существенно различается по причине неотектонического развития в плиоцене и химизме грунтовых вод и почв. Различная геохимическая обстановка на обеих низменностях - содово-сульфатное засоление Приднепровской низменности и более сложной гидрокарбонатно-кальциевой и содовосульфатной минерализации Окско-Донской равнины - главная причина «отсутствия осиновых кустов на Приднепровской низменности» [с. 43].

Интересные исследования, связанные с проявлением высоты местности в структуре ландшафтов Приволжской возвышенности, были проведены Н. И. Дудником [12]. Гипсометрические отметки здесь превышают 350-метровую абсолютную высоту, что стало причиной формирования признаков высотной поясности - появление широколиственных лесов. Дудник Н. И. связывает существование этих ландшафтов с низкогорным типом местности.

2. Исследование вертикальной дифференцииаиии ландшафтов административных районов. Опытов этого варианта немного. Известен пока единственный пример, выполненный Г.И. Денисиком и Л. М. Кирилюком [11].

3. Современное направление исследования высотной дифференциации равнин. На рубеже XX и XXI веков отмечен повышенный интерес к проблеме высотной дифференциации гор и равнин. Авторы используют современные компьютерные технологии и математико-статистические методы. Основное внимание сосредоточено на иерархической организации межкомпонентных связей в ландшафтах и влиянии вмещающей геосистемы на свойства локальных ПТКа $[24,25,13,20]$. При этом А.В. Хорошев однозначно приходит к выводу о том, что «пространственное варьирование всех ха- рактеристик ландшафта наилучшим образом описывается характеристиками рельефа в одной и той же окрестности» $[24$, с. 10$]$. В этой связи он ввел понятие «резонансный уровень» ${ }^{1}$, показывающий отношения между свойством ландшафта и рельефом [24, с. 11].

Проблема иерархии ландшафтных структур в зарубежной литературе находится в поле зрения ландшафтной экологии. Главное внимание обращено к обоснованию отношений между соседними уровнями геосистем и о поиске пространственных масштабов, где взаимодействия компонентов (почв, растительности, температур) максимально тесно [26, 27, 28].

Цель исследования провести анализ орографической зональности в центре Европейской России как конкретное выражение высотной дифференциации равнинных ландшафтов.

\section{МАТЕРИАЛЫ И МЕТОДЫ}

Исходными материалами послужили данные полевых ландшафтных исследований на юге зоны смешанных лесов и лесостепья в течение 19902020 годов. Основной метод исследования - ландшафтно-аналитический.

\section{РЕЗУЛЬТАТЫ И ОБСУЖДЕНИЕ}

Приоритет в установлении географической зональности как всеобщего закона природы принадлежит В. В. Докучаеву. На рубеже XIX и $\mathrm{XX}$ веков в Северном полушарии планеты он выделил семь мировых географических зон. Границы географических зон, обоснованных В.В. Докучаевым, совпадали с ареалами распространения почвенных типов на плакорных поверхностях. Например, бореальной природной зоне соответствуют тундровые (бурые) почвы, северной лесной природной зоне - светло-бурые подзолистые, лесостепной - серые почвы, а степной зоне - черноземы.

После работ Л.С. Берга зональная концепция В. В. Докучаева стала признанной географической реальностью в науках о Земле [7]. Как было показано впоследствии исследованиями А. А. Григорьева и особенно А.А. Григорьева и М.И. Будыко [9] в основе подразделения ландшафтной сферы Земли на географические пояса, зоны и подзоны лежит неодинаковое инсоляционное поступления тепла на горизонтальную (плакорную) поверхность в направлении от экватора к полюсам, а также изменения в том же направлении количе-

1 «Резонансный уровень» А. В. Хорошева по смыслу очень похож на ярусы рельефа $[1,2,4]$. 
ства влаги и соотношения количества тепла и количества влаги.

Ландшафтные исследования южной половины Русской равнины показали, что зональность явление многовариантное. Наряду с горизонтальной, классической, географической зональностью объективно существует склоновая микрозональность $[5,18]$. В ее основе заложена гравитационная энергия. Там, где есть склоны, там обязательно существует их дифференциация на горизонтальные полосы (A, B, C, D). Каждая такая полоса комбинация ландшафтных комплексов низшего таксономического ранга.

В середине XX века в лесостепной части Русской равнины были обнаружены новые нарушения структуры ландшафтов, связанные с неоднородностью орографических условий местности. Оказалось, что колебания относительных и абсолютных высот на равнинах с развитым эрозионным рельефом - главные причины в существовании вертикальной дифференциации ландшафтов.

Открытие новых закономерностей в проблеме высотной дифференциации ландшафтов равнин было прозорливо предсказано профессором Ф. Н. Мильковым. Заканчивая параграф «Высота местности, возраст и структура равнинных ландшафтов» в своей монографии [19] он писал: «Не подлежит сомнению, что региональные аспекты поставленной проблемы исключительно разнообразны и в процессе изучения их, очевидно, будут вскрыты новые закономерности, важные для ландшафтоведческого познания равнин» [с. 186].

Наши исследования карстово-меловых ландшафтов сначала на территории Деснинского полесья, а затем и на Среднерусской возвышенности позволили установить новое явление в структуре вертикальной дифференциации ландшафтов - явление высотной мезозональности [21, 22].

Под высотной мезозональностью мы понимаем такую закономерность в ландшафтной сфере, которая в зависимости от интервалов абсолютных высот на равнинах формирует провинциальные различия ландшафтов - типологических комплексов. А поскольку высотная мезозональность теснейшим образом связана с колебаниями высот эрозионного рельефа в пределах орогенетического типа ландшафтной (природной, географической) зональности, то она находится в одном ряду таких ландшафтных понятий как вертикальная дифференциация и склоновая микрозональность.

Высотная мезозональность на равнинах проявляется в виде ландшафтно-высотных мезозон.
Каждая мезозона ограничена интервалами абсолютных высот. Критериями обособления мезозон выступают - обводненность территории, литологический состав пород и неоген-четвертичная история, неотектоника, материковые оледенения. В конечном итоге разграничение одной мезозоны от другой происходит по внутренней структуре наполняющих их низших ландшафтных комплексов (местностей и урочищ).

Многолетние ландшафтные исследования на ключевых участках (полигонах) Придеснинья (Брянская область и Черниговская область Украины), известняковом севере и меловом юге Среднерусской возвышенности, Брянско-Жиздринском полесье и Окско-Донской равнине показали, что набор мезозон существенно отличается на возвышенных равнинах и равнинах низменных.

На возвышенных равнинах сохраняется полный вариант мезозон, а на низменных - усеченный.

Низменно-гидрогенная мезозона располагается в интервале абсолютных высот 125-150 метров на низменных равнинах. В Придеснинье она развита на западе Брянской области на зандровых пространствах левобережья реки Ипуть и на Окско-Донской равнине на юго-востоке Липецкой и севере северо-востоке Воронежской областей. В структуре мезозоны доминируют гидрогенные супераквальные ландшафты - озерно-болотные, сероольшаниковые, черноольшаниковые и луговоболотные.

Типичным примером лугово-болотного комплекса может рассматриваться карстовое озеро в окрестностях деревни Синявка в Новозыбковском районе Брянской области. Диаметр карстового углубления около 80 метров, а зеркало воды занима-

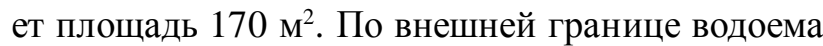
выделяется пояс осок, а на периодически обсыхающих в летний сезон участках произрастают представители мезофитных группировок - тысячелистник хрящеватый (Achillea cartilaginea), мята полевая (Mentha arvensis), дербенник иволистный (Lythrum salicaria), мятлик луговой (Poa pratensis). На внешней периферии карстового озера преобладают заросли череды трехраздельной (Bidens tripartita) и бекмании обыкновенной (Beckmannia eruciformis).

На Среднерусской возвышенности низменногидрогенная мезозона находится на абсолютных отметках 90-120 метров, занимая поймы рек и их русла [23].

Высоко-гидрогенная мезозона приурочена к абсолютным высотам 150-180 метров. В Придес- 
нинье она получила распространение на большей части междуречья Десны и Ипути, а на ОкскоДонской равнине приурочена к малодренированным местным водоразделам левых притоков реки Воронеж.

Высоко-гидрогенная мезозона на Окско-Донской равнине отличается сохранением здесь экстразональных ландшафтов, относящихся к группе нетипичных для лесостепной зоны урочищ.

1. «Солонец Цыганское болото» на водоразделе рек Битюг, Чамлык и Плавица представлен комплексом засоленных лугов, солонцов, заболоченных западин и озер, где произрастает редкий вид кермек опущенный (Limonium tomentellum), поручейник широколистный (Sium latifolium). Гнездятся серый журавль (Grus grus), большая выпь (Botaurus stellaris), большой веретенник (Limosa limosa) и другие водоплавающие виды.

2. «Болото Попово» находится на водоразделбной равнине водораздельную равнину северо-восточнее районного центра Добринское. «Болото Попово» редкое для лесостепного ландшафта сфагновое болото с элементами таежной флоры клюква мелкоплодная (Oxycoccus microcarpus), водяника черная (Empetrum nigrum), пушица стройная (Eriophorum gracile), ива лапландская (Salix lapponum).

3. «Добринские болота» к югу от райцентра Добринское, где на водоразделе сохраняется болотно-галофитный комплекс с солонцами, солодями, лугами. Типичны для урочища осока узколистная (Carex stenophylla), подорожник тонкоцветковый (Plantago tenuiflora), полынь сантонская (Artemisia santonica), очеретник белый (Rhynchospora alba).

4. «Болото Разрезное» - водораздельное сфагновое болото с сохранившейся таежной флорой из клюквы мелкоплодной (Oxycoccus microcarpus), ивы лапландской (Salix lapponum), росянки круглолистной (Drosera rotundifolia), гаммарбии болотной (Hammarbya paludosa), пушицы стройной (Eriophorum gracile).

Возвышенно-гидрогенная мезозона получила распространение на меловом юге Среднерусской возвышенности и Брянско-Жиздринском полесье. Абсолютные отметки находятся в интервале 180220 метров. Если для Среднерусской возвышенности эта мезозона достаточно типична, то ее существование среди полесских ландшафтов явление не столь обычное. По структуре формирующих мезозону комплексов она приближается к типично полесским ландшафтам низменно-гидроген- ной мезозоны. Такие необычные черты возвышенно-гидрогенной мезозоны можно объяснить следующими причинами: 1) близким залеганием к дневной поверхности трещиноватых и сильно обводненных меломергельных пород; 2) маломощным покровом морены и четвертичных суглинков; 3) неотектонической историей развития территории. На не типичность структуры ландшафтов Брянско-Жиздринского полесья впервые указывали участники Калужской экспедиции МОПИ в 1961 году.

Возвыченно-денудационная мезозона в бассейне Средней Десны занимает абсолютные высоты от 180 до 220 метров и тяготеет к окраинам опольских ландшафтов. На меловом юге Среднерусской возвышенности мезозона получила наибольшее распространение. К ней относятся долинно-речные комплексы и примыкающие к ним окраины водоразделов. Из среднерусских ландшафтов мезозоны выделяются реликтовые комплексы «снежные альпы», тимьянники, меловые боры, иссопники.

Вершинно-водораздельная мезозона в бассейне Средней Десны характерна для опольских ландшафтов, где спорадически рассредоточены комплексы с лесостепными чертами. На меловом юге Среднерусской возвышенности в структуре мезозоны сохраняются типично зональные лесостепные ландшафты - лугово-степные, лесные, денудационные куполовидные останцы («шапки»), провальные карстовые воронки. Вершинно-водораздельная мезозона приподнята на высоты 220250 метров.

Холмисто-водораздельная мезозона занимает редко сохраняющиеся спорадические участки на Среднерусской возвышенности с абсолютными отметками 250 и более метров. Куполовидные останцы («шпили») и гряды, ячеистые и бороздчатые микрокарры - характерные комплексы холмисто-водораздельной мезозоны.

\section{ЗАКЛЮЧЕНИЕ}

Центр Русской равнины - регион, где орографический вариант зональности представлен разнообразным спектром высотно-ландшафтных мезозон. На возвышенных равнинах спектр мезозон полный - низмено-гидрогенная; высоко-гидрогенная; возвышенно-гидрогенная; возвышенно-денудационная; вершинно-водораздельная и холмистоводораздельная. На низменных равнинах спектр ландшафтно-высотных мезозон усеченныци - низмено-гидрогенная; высоко-гидрогенная и возвышенно-гидрогенная. 
Особо следует отметить, что граница высотных интервалов между ландшафтно-высотными мезозонами не всегда жестко сохраняется. Допускается скользящий вариант грании между мезозонами при переходе с возвышенных равнин к низменным и наоборот. Например, на Среднерусской возвышенности низмено-гидрогенная мезозона находится в интервале абсолютных высот 90120 метров, а на Окско-Донской низменности и зандровых равнинах в бассейне Ипути интервал высот 125-150 метров.

Скользящий вариант границ между ландшафтными комплексами не такой редкий прием. Им пользовался Ф. Н. Мильков при установлении границ микрозон, а Г.Е. Гришанков при разграничении зональных систем материков [10].

Картирование структурных элементов мезозон на ключевых участках показало существенные различия в рисунке урочищ и типов местности на возвышенных и низменных равнинах [6]. Структурная композиция комплексов на возвышенностях имеет паутиновидные, витиеватые линии границ, высокую их плотность на единицу площади и как следствие резкое снижение площадей невыявленных эрозией поверхностей, появление щитовидных плакоров. Противоположный внешний вид структурные комплексы приобретают на низменностях - линии границ плавные, растянутые, площадь плакорных местностей с невыявленными эрозией поверхностями (ровняди) возрастает.

Принятые нами относительно жесткие интервалы границ мезозон создает впечатление их изолированности друг от друга. Однако такое впечатление не отвечает действительности. Мезозоны между собой (особенно на возвышенных равнинах) находятся в катенарных ${ }^{2}$ отношениях. В ландшафтной географии катена отображает последовательную смену по топографическому градиенту природно-территориальных комплексов под влиянием поверхностного (денудационного) стока. Наш полевой опыт изучения высотной мезозональности в центре Русской равнины позволяет различать два типа ландшафтных катен. Первый сквозной тип катен отображает смену ландшафтных комплексов от вершинно-водораздельной мезозоны до низменно-гидрогенной. Второй одинарный

\footnotetext{
2 Понятие катена (катенарный комплекс) было предложено Дж. Мильни в 1935 году, чтобы зафиксировать последовательность почвенных разновидностей, сформировавшихся, как правило, на одних и тех же материнских породах, но при разных гипсометрических уровнях, уклонах земной поверхности и характеристиках стока водой [15, с. 34].
}

тип катен отражает на профиле структуру ландшафтных комплексов одной мезозоны.

\section{СПИСОК ЛИТЕРАТУРЫ}

1. Ахтырцева Н. И. Вертикальная структура и вопросы эволюции ландшафтных комплексов Калачеевской возвышенности // Научные записки Воронежского отдела Географического обществва СССР, 1970, вып. 2, с. 53-59.

2. Ахтырцева Н.И. Типы местности и урочища бассейна реки Подгорной // Труды ВГУ, 1957, т. 54, с. 41-52.

3. Белосельская Г. А. Вертикальная дифференциация ландшафтов на низменностях центральной лесостепи Русской равнины // Научные записки Воронежского отдела Географического обществва СССР, 1970, вып. 1, с. 33-44.

4. Бердникова 3.П. О ярусной структуре склонового типа местности Среднерусской возвышенности // Научные записки Воронежского отдела Географического обществва СССР, 1972, с. 26-36.

5. Бережной А.В. Склоновая микрозональность ландиафтов Среднерусской лесостепи. Воронеж, издательство Воронежского государственного университета, $1983.140 \mathrm{c}$.

6. Викторов А.С. Рисунок ландшафта. Москва, Мысль, 1986. 177 с.

7. Герасимов И.П. Учение В.В. Докучаева о зонах природы // В. В. Докучаев и география, Москва, 1946, c. $14-24$.

8. Григорьев А. А. В поисках закономерностей морфологической структуры земного шара // Проблемы физической географии. М.-Л., изд-во АН СССР, 1935, т. 2 , c. 3-41.

9. Григорьев А. А., Будыко М. И. О периодическом законе географической зональности // Доклады AHCCCP, 1956, т. 110, № 1, c. 129-132.

10. Гришанков Г.Е. Ландшафтные уровни материков и географическая зональность // Известия $A H$ СССР. Серия географическая, 1972, № 4, с. 5-17.

11. Денисик Г.И., Кирилюк Л.М. Висотна диференціачія рівнинних ландшафтів України. Вінниця, Едельвейс і К, 2010. 236 с.

12. Дудник Н.И. Высотная поясность ландшафтов на Русской равнине и особенно на Приволжской возвышенности // Науч. записки Воронеж. отдела Геогр. о-ва ССCP, 1965 , с. $18-23$.

13. Еремеева А.П. Разномасштабность факторов дифференциации ландшафтов Буртинской степи (Оренбуржье) // Вестник Московского ун-та. Серия 5. География, 2012, № 4, с. 48-53.

14. Калесник С. В. Основы общего землеведения. Москва, Учпедгиз, 1955. $472 \mathrm{c.}$

15. Лисецкий Ф.Н., Светличный А. А., Черный С.Г. Современные проблемы эрозиоведения. Белгород, Константа, 2012. 456 с.

16. Мильков Ф.Н. О двухъярусной структуре равнинных ландшафтов // Научные доклады выстей школыгеолого-географические науки, 1958, № 1, с. 144-149. 
17. Мильков Ф.Н. О явлении вертикальной дифференциации ландшафтов на Русской равнине // Bonpocbl географии, 1947, сб. 3, с. 87-102.

18. Мильков Ф.Н. Склоновая микрозональность ландшафтов // Научные записки Воронежского отдела Географического общества СССР, 1974, вып. 1, с. 3-9.

19. Мильков Ф.Н. Физическая география: современное состояние, закономерности, проблемы. Воронеж, изд-во Воронеж. ун-та, 1981. 400 с.

20. Сысуев В. В. Морфологический анализ геофизической дифференциации ландшафтов // Известия РАН. Серия географическая, 2003, № 4, с. 36-50.

21. Федотов С. В. Высотная мезозональность - новая реальность в вертикальной дифференциации ландшафтов равнин // Вестник Воронежского государственного университета. Серия География. Геоэкология, 2014, № 1, c. 5-9.

22. Федотов С. В. Карстово-меловые ландшафты как индикаторы высотной мезозональности Придеснинья // Вестник Воронежского государственного университета. Серия География. Геоэкология, 2002, № 1, с. 44-48.

23. Федотов С. В. Структура и динамика низменногидрогенной мезозоны на Верхнем Дону в Липецкой области. Десять лет спустя // Вестник Воронежского государственного университета. Серия: География. Геоэкология, 2017, № 3, с. 69-71.

24. Хорошев А. В. Иерархическая организация межкомпонентных связей в лесных ландшафтах ВосточноЕвропейской равнины // Известия РГО, 2010, т. 142, вып. 5, с. 9-16.

25. Хорошев А. В. Рельеф как фактор полимасштабной организации межкомпонентных связей в ландшафтах Восточно-Европейской равнины // Вестник Московского университета. Серия 5. География, 2010, № 3, c. $35-42$.

26. Dorner B., Lertzman K., Fall J. Landscape pattern in topographically complex landscaes; issues and techniques for analysis // Landsc. Ecology, 2002, v. 17, pp. 729-743.

27. Myster R.W., Thomlinson J. R., Larsen M.C. Predicting landslide vegetation in patches on landscape gradients in Puerto Rico // Landsc. Ecology, 1997, v. 12, pp. 299-307.

28. Phillips J. D. Global and local factors in earthsurface systems // Ecol. Modelling, 2002, v. 149, pp. 257-272.

Конфликт интересов: Автор декларирует отсутствие явных и потенциальных конфликтов интересов, связанных с публикацией настоящей статьи.

Поступила в редакичю 21.12.2018

Принята к публикации 26.07.2020

UDC 911.52:551.448

ISSN 1609-0683

DOI: https://doi.org/10.17308/geo.2020.3/3017

\title{
Altitudinal Mesozonality - Version of Orographic Zoning of the Landscapes of the Centre of the Russian Plain
}

\author{
S. V. Fedotov $\bowtie$ \\ Voronezh State University, Russian Federation \\ (1, Universitetskaya sq., Voronezh, 394018)
}

\begin{abstract}
The purpose of the study is to analyze orographic zoning in the centre of European Russia as a concrete expression of the altitudinal differentiation of plain landscapes. Materials and methods. The initial materials were the data of field landscape studies in the south of the mixed forests and forest-steppe zones during 1990-2020. The main research method is landscape and analytical. Results and discussion. On the basis of the regional field data, the structure of the altitudinal mesozones in the Desna River area, the Oka-Don plain, and the Central Russian Upland is revealed. Each mesozone corresponds to a certain level of absolute heights - low-hydrogenic (125-150 m), highly-hydrogenic (150-180 m), sublime-hydrogenic (180-220 m), sublime-denudation (180-220 m), sublime-watershed (220-250 m) and hilly-watershed (250 m or more). Conclusion. The centre of the Russian Plain is a region where the orographic variant of zoning is represented by a varied spectrum of high-altitude landscape mesozones. On the sublime plains, the spectrum of mesozones is complete - low-hydrogenic; highly-hydrogenic; sublime-hydrogenic; sublime-denudation; apical-watershed and hilly-watershed. On low-lying plains, the spectrum of landscape-high-altitude mesozones is truncated-
\end{abstract}

(C) Fedotov S. V., 2020

凶 Sergey V. Fedotov, e-mail: fsv777@yandex.ru

The content is available under Creative Commons Attribution 4.0 License. 
low-hydrogenic; highly hydrogenic and elevated-hydrogenic. It should be especially noted that the boundary of the altitudinal intervals between the landscape-altitude mesozones is not always rigidly preserved. The sliding version of the boundaries between the mesozones is allowed during the transition from the sublime plains to the low ones and vice versa.

Key words: mesozonality, landscape, orography, plain, mesozones, upland, lowland.

For citation: Fedotov S. V. Altitudinal mesozonality - version of orographic zoning of the landscapes of the centre of the Russian plain. Vestnik Voronezskogo gosudarstvennogo universiteta. Geografia geoekologia, 2020, No. 3, pp. 3-12. (In Russ.) DOI: https://doi.org/10.17308/geo.2020.3/3017

\section{REFERENCES}

1. Akhtyrtseva N.I. Vertikal'naya struktura i voprosy evolyutsii landshaftnykh kompleksov Kalacheevskoy vozvyshennosti [Vertical Structure and Issues of Evolution of Landscape Complexes of Kalacheev Upland]. Nauch. zapiski Voronezh. otdela Geogr. o-va SSSR, 1970, issue 2, pp. 53-59. (In Russ.)

2. Akhtyrtseva N. I. Tipy mestnosti i urochishcha basseyna reki Podgornoy [Types of terrain and gorges of the Podgornaya River Basin]. Trudy VSU, 1957, v. 54, pp. 4152. (In Russ.)

3. Belosel'skaya G. A. Vertikal'naya differentsiatsiya landshaftov na nizmennostyakh tsentral'noy lesostepi Russkoy ravniny [Vertical differentiation of landscapes in the lowlands of the central forest-steppe of the Russian Plain]. Nauch. zapiski Voronezh. otdela Geogr. o-va SSSR, 1970, issue 1, pp. 33-44. (In Russ.)

4. Berdnikova Z.P. O yarusnoy strukture sklonovogo tipa mestnosti Srednerusskoy vozvyshennosti [On the layered structure of the slope type of the Central Russian Uplands]. Nauch. zapiski Voronezh. otdela Geogr. o-va SSSR, 1972, pp. 26-36. (In Russ.)

5. Berezhnoy A. V. Sklonovaya mikrozonal'nost' landshaftov Srednerusskoy lesostepi [Slope microzonality of landscapes of the Central Russian forest-steppe]. Voronezh, Voronezh State University Publ. House, 1983. 140 p. (In Russ.)

6. Viktorov A. S. Risunok landshafta [Landscape drawing]. Moscow, Mysl', 1986. 177 p. (In Russ.)

7. Gerasimov I.P. [The teachings of V.V. Dokuchaev on natural zones]. V. V. Dokuchaev i geografiya [V. V. Dokuchaev and geography], Moscow, 1946, p. 14-24. (In Russ.)

8. Grigor'ev A. A. [In search of regularities of the morphological structure of the globe]. Problemy fizicheskoy geografii [Problems to physical geography]. Moscow-Leningrad, Publ. house of the AS USSR, 1935, v. 2, pp. 3-41. (In Russ.)

9. Grigor'ev A. A., Budyko M. I. O periodicheskom zakone geograficheskoy zonal'nosti [On the periodic law of geographical zoning]. Doklady ANSSSR, 1956, v. 110, no. 1, pp. 129-132. (In Russ.)

10. Grishankov G.E. Landshaftnye urovni materikov i geograficheskaya zonal'nost' [Landscape levels of continents and geographical zoning]. Izvestiya AN SSSR. Seriya geograficheskaya, 1972, no. 4, pp. 5-17. (In Russ.)

11. Denisik G. I., Kirilyuk L. M. Visotna diferentsiatsiya rivninnikh landshaftiv Ukraïni [Free differentiation of ru- ral landscapes of Ukraine]. Vinnytsia, Edelweiss i K, 2010, 236 p. (In Ukr.)

12. Dudnik N.I. Vysotnaya poyasnost' landshaftov na Russkoy ravnine i osobenno na Privolzhskoy vozvyshennosti [High-Rise explanation of landscapes in the Russian Plain and especially in the Volga Upland]. Nauch. zapiski Voronezh. otdela Geogr. o-va SSSR, 1965, pp. 18-23. (In Russ.)

13. Eremeeva A.P. Raznomasshtabnost' faktorov differentsiatsii landshaftov Burtinskoy stepi (Orenburzh'e) [Variety of Differentiation Factors of Burt Steppe Landscapes (Orenburg Region)]. Vestnik Moskovskogo universiteta. Series 5. Geography, 2012, no. 4, pp. 48-53. (In Russ.)

14. Kalesnik S. V. Osnovy obshchego zemlevedeniya [Basics of General Land Studies]. Moscow, Uchpedgiz Publ., 1955. 472 p. (In Russ.)

15. Lisetskiy F. N., Svetlichnyy A.A., Chernyy S.G. Sovremennye problemy eroziovedeniya [Modern problems of erosion studies]. Belgorod, Constanta Publ., 2012. 456 p. (In Russ.)

16. Mil'kov F. N. O dvukh"yarusnoy strukture ravninnykh landshaftov [On the two-storey structure of plain landscapes]. Nauch. dokl. vyssh. shk. Geol.-geogr. nauki, 1958, no. 1, pp. 144-149. (In Russ.)

17. Mil'kov F. N. O yavlenii vertikal'noy differentsiatsii landshaftov na Russkoy ravnine [On the phenomenon of vertical landscape differentiation in the Russian Plain]. Voprosy geografii, 1947, coll. 3, pp. 87-102. (In Russ.)

18. Mil'kov F. N. Sklonovaya mikrozonal'nost' landshaftov [Slope microzonality of landscapes]. Nauchnye zapiski Voronezhskogo otdela Geograficheskogo obshchestva SSSR, 1974, no. 1, pp. 3-9. (In Russ.)

19. Mil'kov F. N. Fizicheskaya geografiya: sovremennoe sostoyanie, zakonomernosti, problemy [Physical geography: current state, regularities, problems]. Voronezh, Voronezh University Publ. House, 1981. 400 p. (In Russ.)

20. Sysuev V. V. Morfologicheskiy analisis geofizicheskoy differentsiatsii landshaftov [Morphological analysis of geophysical differentiation of landscapes]. Izvestiya RAN. Seriya geograficheskaya, 2003, no. 4, pp. 36-50. (In Russ.)

21. Fedotov S.V. Vysotnaya mezozonal'nost' - novaya real'nost' v vertikal'noy differentsiatsii landshaftov ravnin [Altitudinal mesozonation - anew reality in the vertical differentiation of landscapes of plains]. Vestnik Voronezhskogo gosudarstvennogo universiteta. Geografiya geoekologiya, 2014, no. 1, pp. 5-9. (In Russ.) 
22. Fedotov S. V. Karstovo-melovye landshafty kak indikatory vysotnoy mezozonal'nosti Pridesnin'ya [KarstChalky landscapes as the indicators of a high-rise mesozonality of the Desnin region]. Vestnik Voronezhskogo gosudarstvennogo universiteta. Geografiya geoekologiya, 2002, no. 1, pp. 44-48. (In Russ.)

23. Fedotov S. V. Struktura i dinamika nizmenno-gidrogennoy mezozony na Verkhnem Donu v Lipetskoy oblasti. Desyat' let spustya [Structure and dynamics of the lowpitched hydrogenous mesozone upon the Upper Don in the Lipetsk Region. Ten years later]. Vestnik Voronezhskogo gosudarstvennogo universiteta. Geografiya geoekologiya, 2017, no. 3, pp. 69-71. (In Russ.)

24. Khoroshev A.V. Ierarkhicheskaya organizatsiya mezhkomponentnykh svyazey v lesnykh landshaftakh Vostochno-Evropeyskoy ravniny [Hierarchical organization of inter-component connections in forest landscapes of the East European Plain]. Izvestiya RGO, 2010, v. 142, issue 5, pp. 916. (In Russ.)

кандидат географических наук, заведующий кафедрой рекреационной географии, страноведения и туризма Воронежского государственного университета, г. Воронеж, Российская Федерация,

ORCID: https://orcid.org/0000-0002-4969-7166, e-mail: $\underline{\text { fsv777@yandex.ru }}$
25. Khoroshev A. V. Rel'ef kak faktor polimasshtabnoy organizatsii mezhkomponentnykh svyazey v landshaftakh Vostochno-Evropeyskoy ravniny [Relief as a factor of polyscale organization of inter-component connections in the landscapes of the East European Plain]. Vestnik Moskovskogo universiteta. Seriya 5. Geografiya, 2010, no. 3, pp. 3542. (In Russ.)

26. Dorner B., Lertzman K., Fall J. Landscape pattern in topographically complex landscaes; issues and techniques for analysis. Landsc. Ecology, 2002, v. 17, pp. 729-743.

27. Myster R. W., Thomlinson J. R., Larsen M. C. Predicting landslide vegetation in patches on landscape gradients in Puerto Rico. Landsc. Ecology, 1997, v. 12, pp. 299307.

28. Phillips J. D. Global and local factors in earthsurface systems. Ecol. Modelling, 2002, v. 149, pp. 257-272.

Conflict of interests: The author declares no information of obvious and potential conflicts of interest related to the publication of this article.

Received: 21.12 .2018 Accepted: 26.07.2020

Sergey V. Fedotov

Cand. (Geogr.) Sci., Associate Professor, the Head of the Department of Recreational Geography, Country Studies and Tourism, Faculty of Geography, Geoecology and Tourism, Voronezh State University, Voronezh, Russian Federation, ORCID: https://orcid.org/0000-0002-4969-7166, e-mail: fsv777@yandex.ru 